CONFERENCES AND PROGRAMS DEALING WITH AUSTRIAN HISTORY

The American Historical Association Convention at Washington, D. C., December 28-30, 1964

Two sessions of the American Historical Association Convention in Washington, D. C., on December 28-30, 1964, dealt in part with the Habsburg monarchy. The first was the program on "Religious Diversity and National Conformity in South-Eastern Europe," of which John C. Campbell, of the Council on Foreign Relations, was chairman. The second was the joint session of the American Historical Association and the Conference Group for Central European History, at which the topic for discussion was "Fifty Years After: the World War I Alliance of the Central Powers in Retrospect." The chairman of this session was Robert A. Kann, of Rutgers University.

On the first of these two programs Radu R. Florescu, of Boston College, among other things, emphasized Habsburg policy in Transylvania and its influence on Rumanian nationalism in a paper on "The Uniate Church-Catalyst of Romanian National Consciousness." As the Rumanian nation's first intelligentsia, the Uniate clergy played an important role in the development of Rumanian nationalism, especially after the Habsburgs gave the Uniates permission to train the clergy in the area itself. The seminaries created for this purpose often demonstrated that they had a greater interest in history than in theology, and various Uniate scholars did a great deal to awaken nationalism. The impact of Uniate scholars and teachers was not limited to the clergy and upper classes but affected people in all ranks of society.

In a paper on ' ' $\mathrm{J}$ ' for Jugoslavia-The Reform of Vuk Karadžić," James Clarke, of the University of Pittsburgh, also emphasized the closeness of the links between religion and nationalism in Eastern Europe-an area where nationalism and religion are intertwined. Karadžić's great contribution, of course, was the invention of the literary Serbian language and his publication of Serbian folk songs. He put Serbian literature on the map and provided the Serbs with the background for a common Serbian nationalism.

The "commentator," Traian Stoianovich, of Rutgers Uni- 
versity, noted that whereas Florescu indicated that religion was much more important than language, Clarke assigned a much higher value to language than to religion in the development of nationalism. Stoianovich added that in his opinion language was important to the diffusion of both religion and nationalism. In fact, he maintained, since religious leaders intent on maintaining orthodoxy are bound to the "old language," making a change in language or script is often tantamount to changing a religion. It is especially for this reason that so much opposition was expressed to Karadžić's language reforms, because they threatened the very basis of Serbian cultural values and to break up the monopoly of the Orthodox clergy.

In his paper on "The Political Cohesion of the Alliance" at the session on "Fifty Years after: the World War I Alliance of the Central Powers in Retrospect," Hajo Holborn, of Yale University, retraced the story of the relations between Germany and Austria-Hungary before the war. The strong cohesion between the two, he said, was clearly demonstrated by what took place during the weeks which followed June 28, 1914. In 1914 Germany treated Austria-Hungary as an equal because of the deep concern of the German officials over the military situation. However, as the Germans became more confident over the turn of military events in 1915 they adopted a more imperious attitude towards Austria-Hungary. As the war progressed and the Austrian capability to fight weakened, the Germans became more and more disdainful of their ally. Furthermore, whereas the Germans had annexionist aims both in the East and the West throughout the course of the war, they never allowed the Austrians clearly to formulate their own war aims. Had the Central Powers emerged from the war even as modest victors, it is evident that Austria would have earned no more than the status of Germany's major satellite.

Speaking on "The Military Cohesion of the Alliance," Gordon Craig, of Stanford University, gave interesting evidence of the lack of coordination between the military officials of the two empires prior to Sarajevo. There was a lamentable lack of planning, for which the Germans were as responsible as the Austrians, and there was a surprising lack of communication between the general staffs. Since Von Schlieffen had little trust in the ability of the Austrians to keep secrets, 
the Germans communicated nothing of importance to them. Von Schlieffen made decisions independently and then, often to their resentment, he notified the Austrians about them. As a consequence, there was no coherence in plans and operations between the two general staffs when the war broke out, and the Germans knew next to nothing about the real strength of the Austrian army. During the war the failure of the German offensive in the West and their lack of ability to support the war on the Eastern front led to Austrian complaints about German failures and to disparaging remarks by the Germans about the incapability of the Austrian army to fight. There were numerous disagreements and considerable bad blood between the officers of the two armies. As the war continued, Conrad believed more and more that victory would mean Austria's submission to a German-dominated Europe.

Of the two "commentators," Klaus Epstein, of Brown University, agreed with the views expressed by Holborn and Craig, adding that the alliance between Germany and Austria held together during the war mainly because Austria had no other choice. He also pointed out that the fundamental solidarity of the alliance was never questioned until the collapse of the Austro-Hungarian monarchy in 1918. The second "commentator," Gerhard L. Weinberg, of the University of Michigan, while agreeing with the views in Craig's paper, raised the question of whether improved liaison between the two staffs might not have led to greater strife in the political sphere.

\section{Other Conferences}

Two of the papers read at a session on "Nationalism in East Central Europe" at the Far Western Slavic Conference at Claremont, California, on April 10-11, 1965, dealt with Austrian history. George Bárány, of the University of Denver, read a paper on "Hungary," and Joseph Zacek, then of Occidental College, one on "Czechoslovakia." The chairman of the session was Peter Sugar, of the University of Washington. Among the commentators were Frederick Heymann, of the University of Alberta; Richard C. Raack, of California State College at Long Beach; and Gunther E. Rothenberg, of the University of New Mexico.

Stanley Kimball, of Southern Illinois University, read a 
paper on "Slavic Intellectual Societies in Nineteenth Century Austria" at the Bi-State (Kansas and Missouri) Slavic Conference at the University of Missouri at Kansas City on October 16, 1965.

\section{ADDITIONS TO LIBRARY COLLECTIONS}

The Colorado State University library has recently acquired about $\mathbf{5 0 0}$ items on Hungarian literature and history. Most of them deal with the nineteenth and twentieth centuries.

The library of Southern Illinois University at Edwardsville has recently procured more than 500 volumes on all phases of Hungarian culture, life, and history. Most of the works are in English. Among them is a good collection on Louis Kossuth.

The Lypynsky East European Institute (1204 West Lindley Ave., Philadelphia, $\mathrm{Pa}$. 19141) possesses a valuable collection of material dealing with the history of Galicia under Habsburg rule and Austro-Ukrainian relations in 1918. Detailed information about the collection may be obtained from Mr. Eugene Zyblykevych, the director of the Institute.

Papers relating to the Georgia Salzburgers are in the De Renne collection at the University of Georgia and in the library of the Salzburger Society at Savannah.

The University of Michigan library has recently acquired a set of the stenographic protocols of the proceedings of the Hungarian parliament which is almost complete for the period between 1861 and 1935. In addition, it has purchased a complete set of the stenographic protocols for the 1st-22nd sessions (1861-1917) of the Austrian Haus der Abgeordneten and of the 1st-12th sessions (1861-1918) of the Herrenhaus. Except for the fact that the protocols for the 47 th and 48 th sessions are missing, the library has also acquired a complete set of the stenographic protocols of the 1st-49th sessions (1861-1918) of the Delegation des Reichsrates.

Among other volumes, the Rice University library has recently acquired the following items which might be of interest to the readers of the Yearbook: Die Presse, December, 1899-1918 and July, 1920-January 20, 1939 (microfilm); Arbeiter Zeitung, January, 1932-February 12, 1934, and 